\title{
Tourismophobia or touristification? An analysis of the impacts of tourism in Poblenou, Barcelona
}

\author{
Turismofobia ou turistificação? Uma análise sobre os \\ impactos da gentrificação turística em Poblenou, \\ Barcelona
}

\section{Tarciso Binoti Simas \\ Sônia Azevedo Le Cocq de Oliveira Ana Belén Cano-Hila}

\begin{abstract}
B

arcelona has been investing strategically in its infrastructures and in a new image to attract investments and tourists, especially from the Olympic project. The transformation impacts in favour of tourism, real estate and entertainment businesses have sparked a recent debate about tourismophobia and touristification. Taking this into account, this article aims to discuss the main impacts of tourism gentrification in Poblenou, Barcelona. This research analyses real estate valuation, the evolution of services in tourism and their conflicts in Poblenou considering a mixture of quantitative and qualitative data collected by bibliographic and documentary sources, spot observations and interviews conducted with the population involved. Despite the complexity that this topic involves, this analysis of tourism impacts in Poblenou contributes by bringing more clarity to this controversial discussion about tourismophobia and touristification. It is important to understand that, despite the positive impacts for the economy in terms of generating income and jobs, there are negative impacts, such as the increase in the cost of living, residents' decrease in quality of life and the exodus of part of its population.
\end{abstract}

Keywords: Tourismophobia. Touristification. Tourism gentrification. Barcelona. Poblenou.

${ }^{1}$ Tarciso Binoti Simas ${ }^{1}$ Universidade Federal do Sul e Sudeste do Pará Santana do Araguaia - PA - Brasil

${ }^{2}$ Sônia Azevedo Le Cocq de Oliveira 2Universidade Federal do Rio de Janeiro Rio de Janeiro - RJ - Brasil

${ }^{3}$ Ana Belén Cano-Hila ${ }^{3}$ Universitat de Barcelona Barcelona - Catalunha - Espanha

Recebido em 21/04/20 Aceito em 22/08/20

\section{Resumo}

Barcelona vem investindo estrategicamente em suas infraestruturas e em uma nova imagem para atração de investimentos e de turistas, sobretudo a partir do Projeto Olímpico. Os impactos das transformações em prol dos negócios turísticos, imobiliários e de entretenimento têm gerado um recente debate entre turismofobia e turistificação. Diante disso, este artigo busca discutir os principais impactos da gentrificação turística em Poblenou, Barcelona. Esta pesquisa analisa a valorização imobiliária, a evolução dos serviços hoteleiros e seus conflitos em Poblenou, graças à mescla de dados quantitativos e qualitativos, coletados por fontes bibliográficas, documentais, observação no local e entrevistas à população envolvida. Apesar da complexidade que este tema envolve, esta análise sobre os impactos do turismo em Poblenou contribui para trazer maior clareza sobre essa polêmica discussão entre turismofobia e turistificação. É importante entender que, apesar dos impactos positivos para a economia na geração de renda e de empregos, há impactos negativos, tais como o aumento do custo de vida, a diminuição da qualidade para seus moradores e o exodo de parte de sua população.

Palavras-chave: Turismofobia. Turisficação. Gentrificação turística. Barcelona. Poblenou.

SIMAS, T. B.; OLIVEIRA, S. A. Le C. de; CANO-HILA, A. B. Tourismophobia or touristification? An analysis of the impacts 117 of tourism in Poblenou, Barcelona. Ambiente Construído, Porto Alegre, v. 21, n. 3, p. 117-131, jul./set. 2021. ISSN 1678-8621 Associação Nacional de Tecnologia do Ambiente Construído. http: //dx.doi.org/10.1590/s1678-86212021000300541 


\section{Introduction}

The city of Barcelona in Spain boasts major tourist, cultural, historical, entertainment and summer attractions. Its efforts in urban transformation, marketing campaigns and strategic positioning have increased the tourism sector, showing significant growth from 2010 to 2016 (the year before the La Rambla attack), when the city received 9,065,650 tourists and raised 24 million euros in tax on tourist establishments (BARCELONA, 2017). Despite the economic gains, this development has caused negative impacts to its population, such as an increase in the cost of living, the exodus of part of the population, manipulation of its identity, among other conflicts. In 2017, claims against tourism sparked a recent debate on touristification and tourismophobia. Among so many tourist areas, the Poblenou district was chosen to further this investigation due to the profound changes since the Olympic project and its tourism potential. Thus, this study aims to discuss the main impacts of tourism gentrification in Poblenou. This is a recent discussion that has an important link between urban and tourism studies.

\section{Theoretical reference}

Part of the tourist boom in Barcelona can be explained by investments in cultural and entertainment facilities, infrastructure, events and marketing undertaken to attract investment and tourists since the 1980s, including major efforts to host the 1992 Olympics. This Olympic Project combined various "ingredients" of American strategic planning, whose fragmented "model" of urban policy turned city marketing into a new local economic agenda for building a "brand" to attract investors, tourists and consumers (COMPANS, 2005). Inspired by the Harvard Business School's business plan, public administration, previously seen as bureaucratic, assumed a management, strategy, structure and promotion stance similar to the administration of private companies to attract the preference of capital flow (LIMA JUNIOR, 2010; VAINER, 2013). Along these lines, monumental public constructions or cultural anchor mega-enterprises become instruments of power in the world of business and global cities, pioneering this "[...] new frontier of accumulation of power and money - the business of images [...]" (ARANTES, 2013, p. 16).

However, Barcelona differs from previous experiences due to more public resources and the visibility that the international mega-event provided. According to Harvey (2014), the 1992 Olympic Games brought this opportunity to obtain monopoly rents due to the accumulation of symbolic capital and its distinctive features. In this slight transformation, its strategic areas were explored concerning real estate, tourism and entertainment businesses, which resulted, on the one hand, in better infrastructures and public spaces and, on the other, in the increase in the cost of living, in the loss of industrial identity and in socio-spatial segregation processes (SIMAS, 2018). The Olympic Village resulted in eliminating the industrial architecture of the Poblenou neighbourhood and was the first step towards privatization of public space (BORJA; MUXÍ, 2013; MONTANER; MUXÍ, 2014). To do this, there were removals with compensation or financial indemnity, but the promise of allocating $25 \%$ of the village for social housing was not fulfilled (VASCONCELOS-DE-LIMA, 2015).

The success of the Barcelona Games publicised the city worldwide by placing it on the capital flow "global map". In a period of post-Olympic recession, the city took advantage of its "strategic positioning" and started promoting its project as a Barcelona Model for urban operation, or Catalan strategic planning, disseminating it through publications, events and consultancy from some designers to other cities in the world, especially Latin America. New operations were also set up in strategic areas of Barcelona, thus selling "success" in business and in the quality of life, which was restricted to citizens with purchasing power. Associated with mega-events, these urban operations in host cities have been promoting significant socio-spatial transformations, privileging elitist sectors (GIULIANOTTI et al., 2015; HILLER, 2006; ROCHE, 2003).

The 2004 Universal Forum of Cultures [in Barcelona] did nothing other than, even more shamelessly, reproduce this device designed to convert the city into an advertising spot and do so by invoking abstract values that were then associated with the "Olympic spirit" and, twelve years later, those of "peace", "solidarity", "cultural diversity", "sustainability” etc. (DELGADO, 2010, p. 41).

In these operations, Delgado (2010) highlights the sale of a false victory over urban pathologies, a city that does not exist and never existed and a deceptive efficiency in the production of social welfare and formal quality. These are experiences that convert the city into "[...] a luxury commodity, destined for an elite group of potential buyers: international capital, visitors and solvable users [...]" (VAINER, 2013, p. 83). "Wholly consumable objects" are constructed in a "system of signs" that, as defined by Lefebvre (2016, p.

118 Simas, T. B.; Oliveira, S. A. Le C. de; Cano-Hila, A. B. 
73), sell happiness, satisfaction, power, wealth, etc. to inhabitants and tourists; and in terms of the real estate market, not only is a property sold, but rather "urbanism". Jacques (2005) calls this intention of producing an image of the city's brand and promoting a certain worldwide standard of urbanisation, hotels, fast food, etc. to tourists (and not inhabitants) as a city of spectacle. Koolhaas (2014, p. 53) calls this process of homogenisation that reconciles the "futurist" and the "primitive" as a generic city: new skyscrapers, hotels and museums are built while the "present", especially the unhealthy, dangerous sex-associated space, is condemned and devastated until it becomes history and business for tourists to warm themselves "to the heat of an extinct volcano".

Along these lines, gentrification processes become more frequent. This concept was formulated by Ruth Glass in 1964 when describing a phenomenon of housing renovation in the London neighbourhood of Islington considering the exodus of working-class inhabitants (OBSERVATORIO..., 2015). According to Smith (2015), since the 1950s-60s, when it was written by Ruth Glass, gentrification went from a local phenomenon of the housing market to generalisation in the 1990s as a neoliberal urban strategy through global circuits of capital and cultural circulation. Thus, gentrification is understood as a process that converts a devalued neighbourhood, an option for housing and work for the low-income population, into a valued commodity to be consumed by the middle class, companies and tourists, thus expanding the reproduction of capital $^{1}$ in the city into tourist, entertainment and/or real estate businesses. By and large, this phenomenon is stimulated by public and/or private initiatives and is associated with the exodus of a large part of the lowincome population (SIMAS, 2018).

Concerning tourism, this can be understood as "[...] an open, organic system, which cannot be studied as a radically isolated entity [...]", being "[...] its interdisciplinary and transdisciplinary content [...]" (BENI; MOESCH, 2017, p. 454). Thus, the "[...] concept (under construction) of touristification [...]" is also considered "[...] imbued with dynamism and used to explain a movement that is not only sectoral [...]" (CALVENTE, 2013, p. 122). By associating urban studies with territories that undergo touristification, that is, a transformation into a tourist location, they are susceptible to negative impacts. Dias (2008) cites everything from the culture clashes, values and moral behaviours to the transformation of the work structure, trade and consumption patterns, the saturation of infrastructures, installations and facilities and the excess of standardisation. Thus, the real estate business is combined with the economic and political change for tourism resulting in gentrification and touristification processes. In other words, the resident and working population can be replaced by new tourist businesses. This phenomenon is also known as "tourism gentrification" which, according to Mendes (2017, p. 491), would be the "[...] transformation of popular and historic neighbourhoods in the city/centre into places of consumption and tourism, by expanding the recreation function, leisure or tourist accommodation $[\ldots]$ ".

This tourist accommodation became popular through home sharing platforms, such as Airbnb (Air Bed and Breakfast), founded in 2008. Its expansion is due, on the one hand, to being a more economical alternative than staying in a hotel and, on the other hand, because it is more profitable than renting out to residents. Over time, this "sharing" (rent) started in properties following a high standard that are intended only for tourists, including specific real estate agents to manage this type of rental. Thus, many traditional houses in tourist areas are replaced by tourist apartments resulting in the exodus of the low-income population and their difficulty in accessing housing.

In Barcelona, Montaner and Muxí (2014) point out that the city has invested riskily in tourism monoculture, mainly after the 2004 Forum and the Mayor Joan Clos administration (1997-2006), which sought to increase the number of tourists and hide "social problems" through the Civic Standard. According to Porretta (2013), these measures follow a neoconservative philosophy that "seems" to exclude certain social groups through measures contrary to begging, prostitution and consumption of alcoholic beverages in public spaces and are associated with closing public areas, getting rid of benches and creating panoptic spaces watched by cameras. The author also criticises the touristification of central neighbourhoods, such as Ciutat Vella, which reached the critical point of increasing housing prices, driving out inhabitants, trivialising the landscape and radically changing the social and economic fabric.

Moreover, this tourism gentrification is not a phenomenon exclusive to Barcelona. Berlin, Lisbon, the Balearic Islands, Venice, Hong Kong, Thailand, Cambodia, New Orleans and Toronto demonstrate an

${ }^{1}$ For Karl Marx $\left(2013^{*}\right.$, p. 227 apud HARVEY, 2013, p. 92), capital is not a thing, but a process in which "[...] the value originally advanced [...] adds to this greatness more value, or is valued. And this movement turns it into capital [...]".

*MARX, K. O capital: livro I. São Paulo: Boitempo, 2013. 
unhealthy relationship between tourism and its inhabitants (MILANO, 2017). According to Mendes (2017, p. 481), while new tourist businesses are created in Lisbon and Porto, "[...] rents increase exponentially, multiplying evictions of vulnerable residents and closings traditional stores, that is, residential and commercial evictions (displacements) [...]" and/or low housing quality due to the alternative of subleasing rooms.

Calvente (2013, p. 131) warns of the deterritorialisation of the caiçara community in Ilha Bela and that "[...] the construction of a resort did not provide the solution to the problem of the need to migrate in search of better living conditions [...]".

Touristification of the northeastern territories [in Brazil], promoted by regional public policies supported by national policies and external resources, has produced privatisation of public space, spatial segregation and the social exclusion of local populations, without overcoming the regional inequalities that, historically, justify and motivate regional development policies. (OLIVEIRA; OLIVEIRA, 2012, p. 396)

These more recent criticisms of the negative impacts of touristification recall Doxey's irritation index which in the 1970s already indicated a certain hostility of the local population towards tourists (DOMÍNGUEZ, 2018); even considering that the impacts of tourism can affect tourists themselves (PÉREZ, 2009).

In 2017, Barcelona experienced some reactions against tourism, from marches and graffiti to attacks on tourist buses and bicycle rentals for tourists. Considering this, the city held a discussion about tourismophobia. According to Oliveira (2019), this term was in vogue in communication media in 2017 due to the "anti-tourist" movements that, even minority ones, extended throughout Europe. Flores and Vargas (2019, p. 127) state that "[...] there is no exact definition for the term tourismophobia since the theme is relatively recent; however, we can define it as the rejection of everything related to the tourism sector by the local population $[\ldots]$ ".

Vázquez and Davila (2020) define tourismophobia as a phenomenon resulting from fear, social rejection or aversion that local citizens feel towards tourists; but the authors also understand it as the lack of proper tourism management that leads to its rejection.

According to Domínguez (2018, p. 23), the Fundación del Español Urgente recognised the noun tourismophobia as "repudiation to touristification" and "aversion or repulsion to tourism in general". However, the author also points out that neighbourhood associations and activists criticise this term, as "[...] it is not neutral and would serve the interests of sectors of the tourist industries to stigmatise the critical positions on the tourist phenomenon [...]". According to Milano (2018, p. 556), “[...] the current echo of the protests in Barcelona and in other cities of the Spanish State, has been reduced to the political instrumentalisation and sensationalism of the media with the nickname of tourismophobia and/or touristophobia [...]". Huete and Mantecón (2018, p. 9) question whether tourismophobia could become "[...] a concept with useful heuristic potential to guide social reality analysis [...]" or whether it would provide "[...] more confusion or ideological noise, making it difficult to develop this analysis [...]".

Thus, it can be observed that there is little understanding in the academy about tourismophobia because it is a more recent debate, mainly on social networks, and because it touches on issues that involve profit in a certain sector. For a better understanding of these issues, this paper aims to discuss the main impacts of tourism gentrification in Poblenou.

\section{Methodology}

This work carries out an exploratory research to investigate the main impacts of tourism gentrification in the Poblenou neighbourhood in Barcelona, whose concepts are operationalised in the indicators and measurement instruments presented in Table 1.

Table 1 - Operationalisation of concepts

\begin{tabular}{|c|l|l|}
\hline Concepts & \multicolumn{1}{|c|}{ Indicators } & \multicolumn{1}{c|}{ Measuring instruments } \\
\hline \multirow{3}{*}{ Gentrification } & Real estate valuation & Document review \\
\cline { 2 - 3 } & New developments & Observation \\
\cline { 2 - 3 } & Population exodus & Interview \\
\hline \multirow{2}{*}{ Touristification } & Host infrastructure & Document review \\
\cline { 2 - 3 } & Claims & Observation and interview \\
\hline
\end{tabular}

120 Simas, T. B.; Oliveira, S. A. Le C. de; Cano-Hila, A. B. 
Data collection includes research:

(a) documentary, from the Departament d'Estadística del Ajuntament de Barcelona and news;

(b) spot observations, including photographic records and attempt to reside in the place; and

(c) interviews.

The field trip took place between April and July 2017, before the La Rambla attack in August and the Catalan independence referendum in October. During the field trip, the plan was to live in the study area, but it was not possible as explained in Gentrification section. The interviews were conducted with individuals over 18 years of age according to the following criteria:

(a) residents and workers;

(b) technicians involved with projects;

(c) researchers who carried out some type of investigation on the case; and

(d) resistance movements to gentrification and touristification.

This project was approved by the Research Ethics Committee at the Hospital Universitário Clementino Fraga Filho at the Federal University of Rio de Janeiro (UFRJ in Portuguese) on Plataforma Brasil.

The study area is delimited in the area popularly known as Poblenou in the Sant Martí District in Barcelona that corresponds to the new definition of neighbourhoods made in 2006: El Parc i la Llacuna del Poblenou, Provençals del Poblenou, La Vila Olímpica del Poblenou, El Poblenou, Diagonal Mar i el Front Marítim del Poblenou and El Besos i el Maresme. We chose this area due to the huge transformation it has undergone since the 1980 s by the Olympic Project that preceded various interventions, such as specific cultural facilities designed by stellar architects and major works, as shown in Figure 1.

\section{Figure 1 - Location of Poblenou and its main interventions}

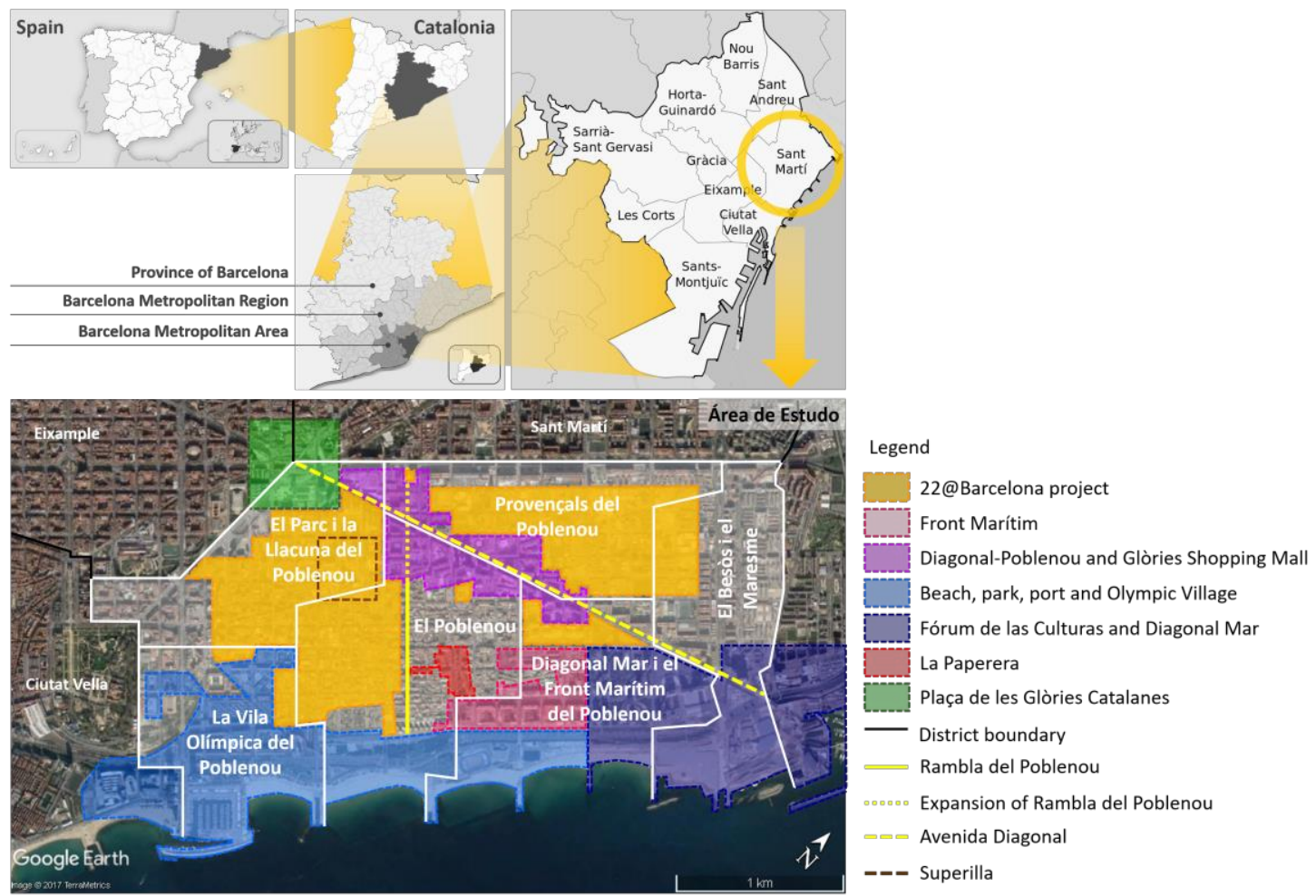

Source: authors' own work using Google Earth aerial image (2017). 


\section{Results}

\section{Gentrification}

It can be observed that both Barcelona and Sant Martí experienced an appreciation of residential rent from 2000 to 2010 and a devaluation or low appreciation from 2010 to 2015, as shown in Table 2. As of 2015, it can be observed that some neighbourhoods have higher absolute and relative values in relation to the city. The sale price of new homes in Barcelona has been going up since 2015, as shown in Table 3; some neighbourhoods have higher values and absolute values. According to Table 4, regarding the sale of used property, from 2001 to 2009, Barcelona and Sant Martí underwent appreciation. In the early 2010s, there was a devaluation or low appreciation. From 2014, Sant Martí and some neighbourhoods have become more valued than the average in Barcelona.

Table 2 - Average residential rental price $\left(€ / \mathrm{m}^{2}\right)$ in absolute and relative values

\begin{tabular}{l|c|c|c|c|c|c}
\hline & $\mathbf{2 0 0 0}$ & $\mathbf{2 0 1 0}$ & $\mathbf{2 0 1 4}$ & $\mathbf{2 0 1 5}$ & $\mathbf{2 0 1 6}$ & $\mathbf{2 0 1 7}$ \\
\hline Barcelona & 5.7 & 11.7 & 10.2 & 10.3 & 11.6 & 13 \\
\hline & - & $105 \%$ & $-13 \%$ & $1 \%$ & $13 \%$ & $12 \%$ \\
\hline Sant Martí & 5.5 & 11.2 & 10.07 & 9.72 & 10.9 & 12.7 \\
\hline Llacuna & - & $104 \%$ & $-10 \%$ & $-3 \%$ & $12 \%$ & $17 \%$ \\
\hline & - & - & 11.04 & 9.8 & 12.1 & 13.1 \\
\hline Vila Olímpica & - & - & - & $-11 \%$ & $23 \%$ & $8 \%$ \\
\hline & - & - & 12.37 & 12.9 & 15.8 & 16.3 \\
\hline El Poblenou & - & - & - & $4 \%$ & $22 \%$ & $3 \%$ \\
\hline & - & - & - & $-7 \%$ & $12 \%$ & $13 \%$ \\
\hline Diagonal Mar & - & - & 10.82 & 11.6 & 11.8 & 15.8 \\
\hline & - & - & - & $7 \%$ & $2 \%$ & $34 \%$ \\
\hline El Besòs & - & - & 8.51 & 8.4 & 8.5 & 9.5 \\
\hline & - & - & - & $-1 \%$ & $1 \%$ & $12 \%$ \\
\hline Provençals & - & - & $9 . .54$ & 9.1 & 10.6 & 13.2 \\
\hline & - & - & - & $-5 \%$ & $16 \%$ & $25 \%$ \\
\hline
\end{tabular}

Source: authors' own work using data from DPAB (DEPARTAMENT..., 2018).

Note: (1) data for the 1st quarter of each year; and (2) relative value refers to the last available previous data.

Table 3 - Sale price of new housing $\left(€ / \mathrm{m}^{2}\right)$ in absolute and relative values

\begin{tabular}{l|c|c|c|c}
\hline & $\mathbf{2 0 1 3}$ & $\mathbf{2 0 1 4}$ & $\mathbf{2 0 1 5}$ & $\mathbf{2 0 1 6}$ \\
\hline Barcelona & 3197.5 & 3116.2 & 3237.0 & 3849.7 \\
\hline & - & $-3 \%$ & $4 \%$ & $19 \%$ \\
\hline Llacuna & 1691.3 & 1498.4 & - & 3313.8 \\
\hline & - & $-11 \%$ & - & $121 \%$ \\
\hline Vila Olímpica & - & 2939.90 & - & - \\
\hline & - & - & - & - \\
\hline El Poblenou & 3061.0 & 3302.3 & 3182.3 & 4944.9 \\
\hline & - & $8 \%$ & $-4 \%$ & $55 \%$ \\
\hline Diagonal Mar & 3213.6 & 4077.6 & - & - \\
\hline & - & $27 \%$ & - & - \\
\hline El Besòs & 2548.4 & 2472.6 & 3615.4 & 2670.1 \\
\hline & - & $-3 \%$ & $46 \%$ & $-26 \%$ \\
\hline Provençals & 3917.2 & 3331.0 & 1968.5 & 2159.1 \\
\hline & - & $-15 \%$ & $-41 \%$ & $10 \%$ \\
\hline
\end{tabular}

Souce: authors' own work using data from DPAB (DEPARTAMENT..., 2018).

Note: (1) in the gaps without an estimate, the observation number was less than 10; and (2) relative value refers to the last available previous data. 
Table 4 - Sale price of second-hand house $\left(€ / \mathrm{m}^{2}\right)$

\begin{tabular}{l|c|c|c|c|c|c|c|c|c}
\hline & $\mathbf{2 0 0 1}$ & $\mathbf{2 0 0 9}$ & $\mathbf{2 0 1 0}$ & $\mathbf{2 0 1 1}$ & $\mathbf{2 0 1 2}$ & $\mathbf{2 0 1 3}$ & $\mathbf{2 0 1 4}$ & $\mathbf{2 0 1 5}$ & $\mathbf{2 0 1 6}$ \\
\hline Barcelona & 2115 & 4097 & 4046 & 3548 & 3217 & 3019 & 3188 & 3392 & 3879 \\
\hline & - & $94 \%$ & $-1 \%$ & $-12 \%$ & $-9 \%$ & $-6 \%$ & $6 \%$ & $6 \%$ & $14 \%$ \\
\hline Sant Martí & 1692 & 3710 & 3643 & 3203 & 2854 & 2957 & 3226 & 3530 & 3954 \\
\hline Llacuna & - & $119 \%$ & $-2 \%$ & $-12 \%$ & $-11 \%$ & $4 \%$ & $9 \%$ & $9 \%$ & $12 \%$ \\
\hline & - & - & - & 3271 & 2808 & - & 2779 & 2956 & 3761 \\
\hline La Vila Olímpica & - & - & - & - & $-14 \%$ & - & $-1 \%$ & $6 \%$ & $27 \%$ \\
\hline & - & - & - & - & - & - & 4795 & 4728 & 5365 \\
\hline El Poblenou & - & 3961 & 4165 & 3751 & 3294 & 3446 & 3304 & 3606 & 4223 \\
\hline & - & - & $5 \%$ & $-10 \%$ & $-12 \%$ & $5 \%$ & $-4 \%$ & $9 \%$ & $17 \%$ \\
\hline Diagonal Mar & - & 5417 & 5575 & 4791 & 4248 & 4722 & 5646 & 6506 & 5891 \\
\hline & - & - & $3 \%$ & $-14 \%$ & $-11 \%$ & $11 \%$ & $20 \%$ & $15 \%$ & $-9 \%$ \\
\hline El Besòs & - & 2929 & 2722 & 2337 & 2072 & - & 2002 & 1951 & 2222 \\
\hline & - & - & $-7 \%$ & $-14 \%$ & $-11 \%$ & - & $-3 \%$ & $-3 \%$ & $14 \%$ \\
\hline Provençals & - & 3994 & 3775 & 3213 & 2813 & - & 3069 & 3397 & 3310 \\
\hline & - & - & $-5 \%$ & $-15 \%$ & $-12 \%$ & - & - & $11 \%$ & $-3 \%$ \\
\hline
\end{tabular}

Souce: authors' own work using DPAB data (DEPARTAMENT..., 2018).

Note: (1) in the gaps without an estimate, the observation number was less than $10 ;(2)$ the data are for the $4^{\text {th }}$ quarter of each year; and (3) the relative value refers to the last available previous data.

The search for housing carried out by the researcher during the field trip was useful to understand part of this reality. Room rental is so fierce that search apps have the option of selecting ads up to 48 hours away. In fact, most of the recent ads have already been rented. It was common to make an appointment and receive a cancellation message on the way, as another interested party had just closed a deal. This happened throughout Barcelona, but in Poblenou there was less supply and greater appreciation. The prices of rooms in better conditions started from 600 to 1000 euros having a "tourist" standard. Offers between 400-500 euros were for rooms without a window or in buildings without an elevator. Therefore, we decided to live in the neighbouring and slightly less valued Sant Martí de Provençals neighbourhood.

In the interviews, this valuation was associated with the exodus of former residents and low-income workers who were no longer able to stay in Poblenou considering the increase in the cost of living, especially rent (interviews with resident and researcher at the University of Barcelona (UB); resident; priest from Parròquia del Patriarca Abraham; a participant in the resistance movement; resident in official protection housing; and lifelong resident in Poblenou).

This profile change was observed in two projects that were in progress. In El Poblenou, a project approved in 2008 foresaw the demolition of an old factory and houses whose "owners caused the former tenants to leave" (interview with priest at Parròquia del Patriarca Abraham). Another project, two blocks from the Diagonal Mar beach, intervenes in the neighbouring lots of 3 blocks after demolishing $6740.57 \mathrm{~m}$ including houses, according to Figures 2 and 3.

They are rooms that can accommodate no more than thirty families. The spaces are small, and this induces residents to share not only the corrridors, but also concerns about the future of these spaces and their homes, threatened by an urban plan that was initially approved (EL POBLENOU, 2016, $p$. 7).

Mayor Ada Colau recognises that the city is experiencing an intense process of gentrification and mentions the possibility of establishing a rental price reference for houses and workshops (NACIODIGITAL, 2017); but failed to put into practice.

\section{Touristification}

As shown in Table 5, in the initial years, a significant number of construction and renovation permits were observed, following the number of works carried out for urban interventions, especially in 2002 when Sant Martí was responsible for more than $50 \%$ of hotel licenses in the city. From 2008 , there was a drop in licenses in general and, from 2012, the percentage of hotel licenses increased, demonstrating this accommodation in the real estate market focusing on tourism. 
Figure 2 - Property to be demolished at Carrer Ramon Turró

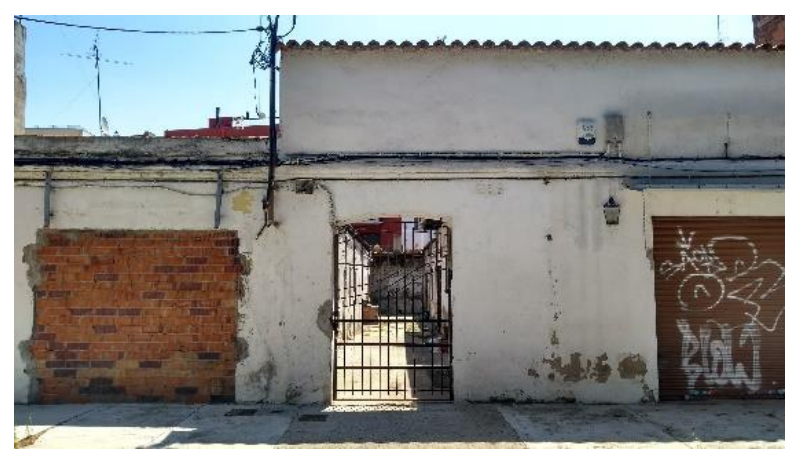

Figure 3 - Common area of property to be demolished at Carrer Ramon Turró

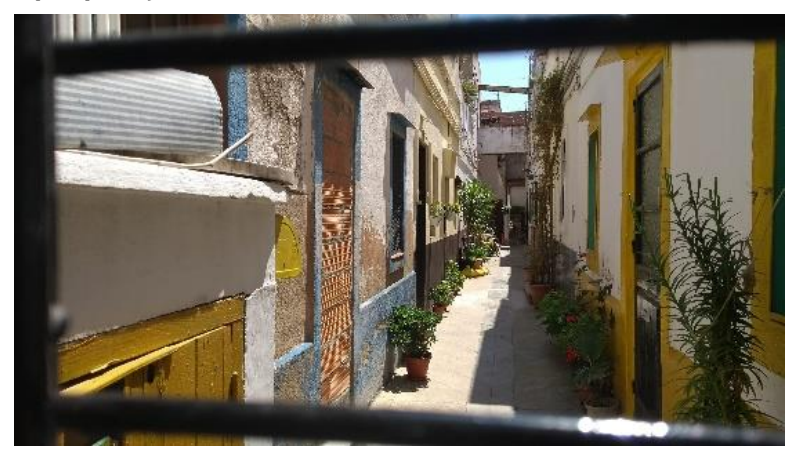

Table 5 - Construction and renovation license per $\mathrm{m}^{2}$ of hotel use and total

\begin{tabular}{c|c|c|c|c|c|c|c}
\hline & \multicolumn{3}{|c|}{ Barcelona } & \multicolumn{3}{c|}{ Sant Martí } & $\begin{array}{c}\text { Hotel capacity } \\
\text { from Sant } \\
\text { Martí/ }\end{array}$ \\
\hline & Year & Hotal & $\begin{array}{c}\text { Hotel } \\
\text { capacity - }\end{array}$ & Total & $\begin{array}{c}\text { Hotel } \\
\text { capacity }\end{array}$ & $\begin{array}{c}\text { Hotel } \\
\text { capacity - } \\
\text { total (\%) }\end{array}$ & $\begin{array}{c}\text { Marcelona (\%) } \\
\text { total (\%) }\end{array}$ \\
\hline 2000 & 743.143 & 85.281 & $11.48 \%$ & 161.167 & 12.550 & $7.79 \%$ & $14.72 \%$ \\
2001 & 684.129 & 82.034 & $11.99 \%$ & 274.110 & 20.301 & $7.41 \%$ & $24.75 \%$ \\
2002 & 985.543 & 204.615 & $20,76 \%$ & 401.315 & 108.101 & $26.94 \%$ & $\mathbf{5 2 . 8 3 \%}$ \\
2003 & 742.900 & 106.714 & $14.36 \%$ & 223.778 & 45.820 & $20.48 \%$ & $\mathbf{4 2 . 9 4 \%}$ \\
2004 & 676.242 & 101.465 & $15.00 \%$ & 126.201 & 516 & $0.41 \%$ & $0.51 \%$ \\
2005 & 898.498 & 122.191 & $13.60 \%$ & 343.553 & 47.642 & $13.87 \%$ & $\mathbf{3 8 . 9 9 \%}$ \\
2006 & 887.911 & 68.275 & $7.69 \%$ & 257.247 & 23.567 & $9.16 \%$ & $\mathbf{3 4 . 5 2 \%}$ \\
2007 & 700.870 & 95.356 & $13.61 \%$ & 163.948 & 13.569 & $8.28 \%$ & $14.23 \%$ \\
2008 & 664.483 & 71.473 & $10.76 \%$ & 181.293 & 3.590 & $1.98 \%$ & $5.02 \%$ \\
2009 & 429.883 & 60.535 & $14.08 \%$ & 128.506 & 20.910 & $16.27 \%$ & $\mathbf{3 4 . 5 4 \%}$ \\
2010 & 320.072 & 29.969 & $9.36 \%$ & 74.074 & 10.221 & $13.80 \%$ & $\mathbf{3 4 . 1 1 \%}$ \\
2011 & 339.087 & 44.654 & $13.17 \%$ & 74.873 & 6.077 & $8.12 \%$ & $13.61 \%$ \\
2012 & 255.320 & 62.712 & $24.56 \%$ & 49.445 & 14.268 & $28.86 \%$ & $22.75 \%$ \\
2013 & 202.305 & 37.119 & $18.35 \%$ & 25.046 & 1.801 & $7.19 \%$ & $4.85 \%$ \\
2014 & 344.314 & 92.618 & $26.90 \%$ & 37.669 & 6.944 & $18.43 \%$ & $7.50 \%$ \\
2015 & 408.647 & 70.557 & $17.27 \%$ & 104.474 & 15.651 & $14.98 \%$ & $22.18 \%$ \\
\hline
\end{tabular}

Souce: authors' own work using data from DPAB (DEPARTAMENT..., 2018).

The relationship between hotel use and total between 2009 and 2015, as shown in Table 6, grew more in Sant Martí and in most neighbourhoods in the study area. Thus, Sant Martí is in $3^{\text {rd }}$ place in the 2015 ranking of hotel infrastructures with 37 of the hotels (DEPARTAMENT..., 2018); in which 15 hotels are in Poblenou (AJUNTAMENT..., 2015, p. 80).

Specifically, in the scope of the 22@ Barcelona project, part of the coefficient of utilisation (2.2 out of a maximum of 3.2) was used to build a hotel. Until "there came a time, with the tourist boom in Barcelona,

124 Simas, T. B.; Oliveira, S. A. Le C. de; Cano-Hila, A. B. 
when the only activity proposed in this area of $22 @$ was hotels. It was a massification" (Interview with City Hall technician).

The proposal of a new hostel with 440 places in the Vila Olimpica aroused surprise, as there was no consultation with the population (interview with resident in an official shelter and priest at the Parròquia del Patriarca Abraham). In 2016, the Associació de Veïns $i$ Veïnes Vila Olímpica launched a petition and protests against the project (EL PERIÓDICO, 2018); but it was not enough to stop it.

In addition to the hotel capacity, tourist accommodation has become an important way of staying and another challenge for the city. As shown in Figure 4, Barcelona experienced a sudden growth in tourist accommodation after sharing platforms were popularised. In addition to this regulated market, there is an informal business that includes subleases. In 2015, 482 illegal tourist homes were registered. In 2016, there were 866 fines of 30 thousand euros to owners and 60 thousand euros to Airbnb and Homeaway platforms (EL DIARIO, 2018).

In 2017, there was a protest in La Rambla with the words "Barcelona is not for sale" and "We will not be driven out" against the subsidies that promote tourism (CARTA..., 2017). As a response, the Plan Especial Urbanístico de Alojamientos Turísticos (Special Urban Plan for Tourist Accommodation) was approved, which limits the number of tourist establishments, including houses, through the declining areas (where new licenses are not allowed); maintenance (where new licenses are allowed only by closing another establishment); permission (where new licenses are still allowed) and other prohibitive ones (such as 22@ Nord). Figure 5 shows these restrictions in the study area and the location of the hotels.

Table 6 - Percentage of area of hotel use by total area in 2009 and 2015

\begin{tabular}{l|c|c|c}
\hline & $\mathbf{2 0 0 9}$ & $\mathbf{2 0 1 5}$ & $\mathbf{2 0 1 5 / 2 0 0 9}$ \\
\hline Barcelona & 1.8 & 2.2 & $+22.22 \%$ \\
Sant Martí & 1.1 & 2.3 & $+109.09 \%$ \\
Llacuna & 0.2 & 3.5 & $+1650.00 \%$ \\
Vila Olímpica & 2.3 & 2.3 & 0 \\
El Poblenou & 0.5 & 3.2 & $+540 \%$ \\
Diagonal Mar & 6.4 & 7.5 & $+17.18 \%$ \\
El Besòs & 0.1 & 1.9 & $+1800.00 \%$ \\
Provençals & 1.1 & 1 & $-9.09 \%$ \\
\hline
\end{tabular}

Souce: authors' own work using data from DPAB (DEPARTAMENT..., 2018).

Figure 4 - Evolution of accommodation for tourist use

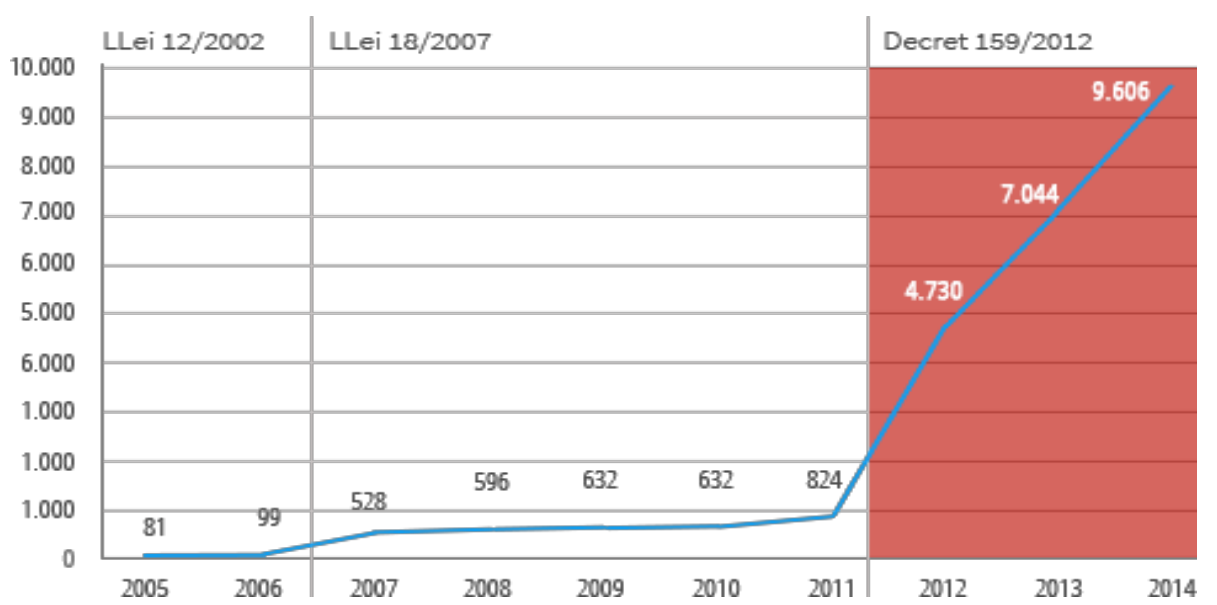

Source: Ajuntament de Barcelona (2018) (Barcelona City Council). 
Figure 5 - Special Urban Plan for Tourist Accommodation and the location of hotels

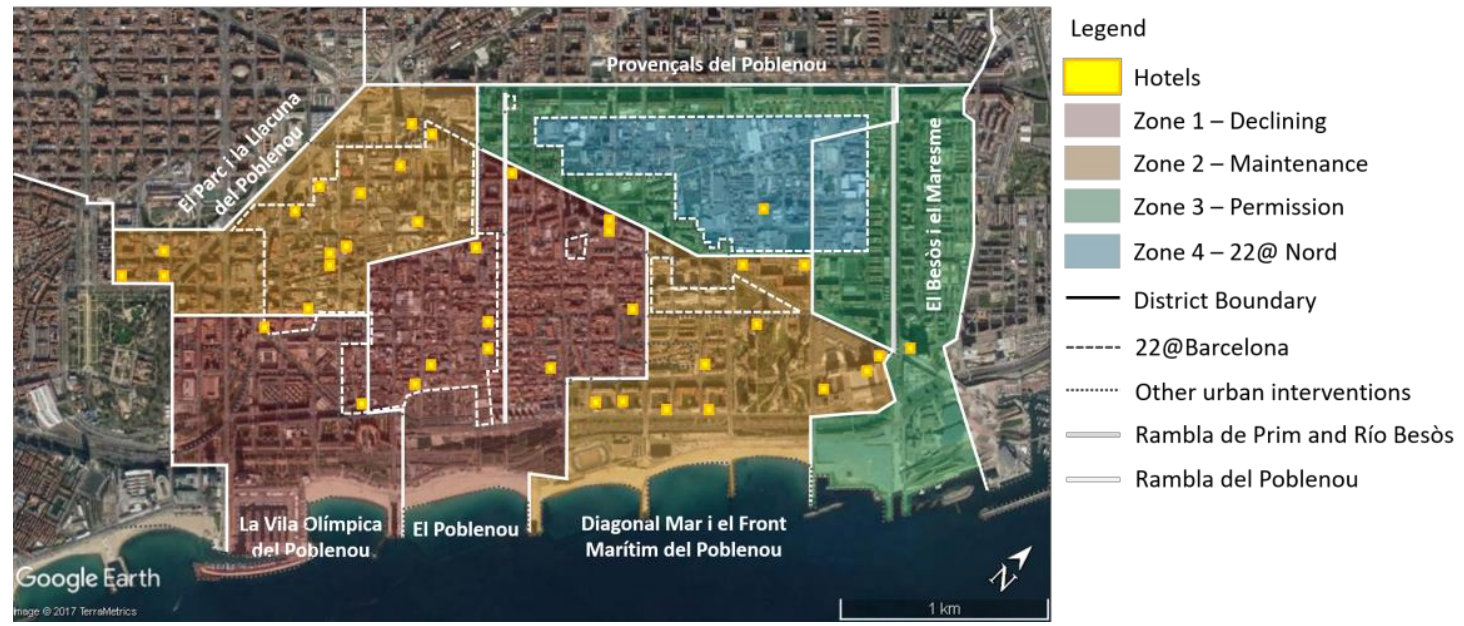

Souce: authors' own work using aerial image of Google Earth (2017).

Note: Hotels surveyed by AB (AJUNTAMENT..., 2015, p. 80) and on the BOOKING website (2018). (classification of hotels, guesthouses, hostels and motels).

In Poblenou, this touristification faces other problems. Most traditional establishments, e.g. lifelong small businesses or nearby shops are being replaced by new cafe services, franchising, etc. catering for the middle class and/or tourism. In addition to the lack of non-tourist services (butchers, stationers, haberdashery, etc.), the cost of consumption for inhabitants rises to that of tourists. An example is the Mercado del Poblenou which, similar to other markets in Barcelona, has become a tourist attraction after being renovated resulting in small shops closing down and the loss of diversity (interview with resident and artist of a collective).

I remember the Poblenou [Market] as it was. It no longer has the essence that it had. Local shops were taken out. Nearby trading was taken out. There are very few. Most had to close. A bakery, a butcher, a fishmonger, a neighbourhood grocery store. Not many. They are very few. You can count them on your fingers. (Interview with a lifelong resident in Poblenou).

Other reported complaints are about tourists who invade local parties, wear swimwear out of context and walk drunk on the streets.

I remember the first time we laughed about it: "look at that crazy person [tourist] going to the beach with a hotel towel". Because people from here go to the beach dressed and carry a bag with a bathing suit and towel in it. An Englishman carrying a towel with the hotel logo on it going to the beach. Now that's something you see every day. (Interview with resident in officially protected housing).

However, the most recurring complaint was about the invasion of tourist services to La Rambla del Poblenou, in restaurant, bar and café terraces. As a result, much of the public space was occupied, making it difficult for the elderly, wheelchair users and baby strollers to circulate. People who sit at a restaurant table in these spaces are forced to consume a meal even if they just want to have a drink with a friend.

Five years ago, there were 12 bars/establishments that had terraces on La Rambla. Now there are 65. [and] suddenly, you can no longer pass through there. [and] if I go to La Rambla in some bars, they will not let me have just a beer, they want me to have dinner. [...] And La Rambla that has always belonged to many of its neighbours, not now, it belongs to tourists. (Interview with resident).

In response, some residents organised themselves in the "Sin Rambla" movement and protested by setting their own tables and chairs for dinner on La Rambla del Poblenou (interview with a resistance movement participant). As a response, in 2015, the City Hall reorganised this public space to limit the use of terraces and allow spaces for circulation and a balanced use.

Poblenou has other protests against touristification. El Antropólogo Perplejo (2017) made a series of photographic records of posters and graffiti about: "gringos go home. Refugees are welcome"; the sale of apartments and tourist licenses; the number of hotels in Poblenou; exodus of neighbours; tourism analogy to colonialism; and the warning that a fruit and vegetable market is not a museum there.

126 Simas, T. B.; Oliveira, S. A. Le C. de; Cano-Hila, A. B. 
On the website Iniciativa Debate (2018), the article "Turismofobia, tu padre" reports many negative questions about tourism.

If you report that drunken gringos stay in illegal apartments and throw up at your door, it is because you hate tourism. [...] Those who hate everything, except wanting to accumulate profits at the expense of exploiting natural, historical and human resources, found in "tourismophobia" their key word for not starting a serious debate [...] Turismofobia, teu pai (Tourismophobia, your father) (INICIATIVA ..., 2018).

In the seminar "Gentrificació $i$ turisme, dues cares de la mateixa moneda?", , held in May 2017 at Hort La Vanguardia, attended by researchers from Observatori d'Antropologia del Conflicte Urbà e da Escola Universitària de Turisme Ostelea (Universitat de Lleida) and collectives such as l'Associació Cultural Els Fumats, plataforma \#EnsPlantem e Veïns en Perill d'Extinció, an argument was put forward that Barcelonians are not against tourism itself, as they themselves are tourists when they travel to other cities. However, they are against the touristification that has been taking place over the last years in Barcelona and that has led to gentrification processes and conflicts with its residents.

\section{Discussion}

Regarding gentrification, as shown in Table 7, the coastal neighbourhoods present absolute values higher than the Barcelona average, in which some have a higher valuation. The exodus of residents (tenants) was reported due to the rising cost of living in Poblenou and the construction of new developments. Subleases of valued rooms is an alternative that demonstrates the precarious quality of housing. The City Hall recognises gentrification, but failed to put the rental price reference into practice.

Regarding tourism, as shown in Table 8, the Sant Martí District became the $3^{\text {rd }}$ in hotel infrastructure and was responsible for most of the city's new licenses. Most neighbourhoods are growing and have a larger hotel area than in the city. Various claims can be observed in Poblenou against the negative impacts of tourism, such as the construction of new establishments, the decline in local commerce, the tourists' behaviour and the invasion of terraces in La Rambla del Poblenou. In response, the City has limited new hotel licenses and reordered La Rambla del Poblenou.

Table 7 - Summary of gentrification

\begin{tabular}{|c|c|c|c|c|c|c|c|}
\hline \multirow{8}{*}{$\begin{array}{l}\text { Real estate } \\
\text { valuation } \\
(\boldsymbol{\Delta}) \text { above } \\
(\boldsymbol{\nabla}) \text { below } \\
\text { or }(=) \text { equal } \\
\text { to average of } \\
\text { Barcelona. }\end{array}$} & \multirow{2}{*}{ Neighbourhood } & \multicolumn{2}{|c|}{ Rent } & \multicolumn{2}{|c|}{ New sale } & \multicolumn{2}{|c|}{ Used sale } \\
\hline & & Absolute & Relative & Absolute & Relative & Absolute & Relative \\
\hline & Llacuna & $\Delta$ & $\nabla$ & $\nabla$ & $\mathbf{\Delta}$ & $\nabla$ & $\Delta$ \\
\hline & Vila Olímpica & $\boldsymbol{\Delta}$ & $\nabla$ & - & - & $\Delta$ & $\nabla$ \\
\hline & El Poblenou & $\Delta$ & $\Delta$ & $\Delta$ & $\Delta$ & $\Delta$ & $\Delta$ \\
\hline & Diagonal Mar & $\Delta$ & $\Delta$ & - & - & $\Delta$ & $\nabla$ \\
\hline & El Besòs & $\nabla$ & $=$ & $\nabla$ & $\nabla$ & $\nabla$ & $=$ \\
\hline & Provençals & $\mathbf{\Delta}$ & $\boldsymbol{\Delta}$ & $\nabla$ & $\nabla$ & $\nabla$ & $\nabla$ \\
\hline Exodus & \multicolumn{7}{|c|}{$\begin{array}{l}\text { Reports on exodus of residents with rising cost of living. } \\
\text { Demolition of houses with exodus of tenants to construct new developments. }\end{array}$} \\
\hline Observation & \multicolumn{7}{|c|}{ Sublease of valued rooms. } \\
\hline $\begin{array}{l}\text { Municipal } \\
\text { power }\end{array}$ & \multicolumn{7}{|c|}{$\begin{array}{l}\text { City Hall recognises gentrification and mentions the possibility of establishing a rental } \\
\text { price reference for houses and workshops; but without putting it into practice until } \\
\text { then. }\end{array}$} \\
\hline
\end{tabular}

${ }^{2}$ Turismofobia, teu pai - Turismophobia, your father.

${ }^{3}$ Gentrification and tourism, two sides of the same coin? 
Table 8 - Summary of touristification

\begin{tabular}{|c|c|c|c|c|c|c|c|}
\hline New licenses & \multicolumn{7}{|c|}{$\begin{array}{l}\text { Sant Martí was responsible for many of the new hotel licenses in Barcelona in } \\
2002,2003,2005,2006,2009 \text { and } 2010 \text {. In 2015, it became the 3rd district } \\
\text { with the largest hotel infrastructure. }\end{array}$} \\
\hline \multirow{4}{*}{$\begin{array}{l}\text { Hotel use } \\
\text { area - total }\end{array}$} & & Llacuna & Vila O. & el Pobl. & Diag. & Besòs & Prov. \\
\hline & 2015 & $\Delta$ & $\bar{\Delta}$ & $\mathbf{\Delta}$ & $\Delta$ & $\boldsymbol{\nabla}$ & $\boldsymbol{\nabla}$ \\
\hline & $2015 / 2009$ & $\Delta$ & - & $\Delta$ & $\Delta$ & $\Delta$ & $\boldsymbol{\nabla}$ \\
\hline & \multicolumn{7}{|c|}{$(\boldsymbol{\Delta})$ above, $(\boldsymbol{\nabla})$ below or $(=)$ equal to average of Barcelona. } \\
\hline Claims & \multicolumn{7}{|c|}{$\begin{array}{l}\text { Banners and protests against tourism in Poblenou. } \\
\text { Against the construction of a hostel with } 400 \text { places. } \\
\text { Decline in local commerce. } \\
\text { Against tourists who wear swimwear in an appropriate context and walk } \\
\text { drunk in the streets. } \\
\text { "Crowded" terraces in La Rambla del Poblenou. }\end{array}$} \\
\hline Public Power & \multicolumn{7}{|c|}{$\begin{array}{l}\text { Special Urban Plan for Tourist Accommodation } \\
\text { Reordering of La Rambla del Poblenou }\end{array}$} \\
\hline
\end{tabular}

Thus, it is understood that Poblenou is going through intense gentrification and touristification processes or, in other words, of tourism gentrification. Considering the claims against the negative impacts of tourism, in 2017 a strong and highly controversial discourse about tourismophobia emerged in the Spanish media. If considered as a phenomenon resulting from fear, social rejection or aversion that local citizens would have towards tourists (VÁZQUEZ; DAVILA, 2020), this research did not find such evidence. During the research, the receptivity and respect of the Barcelonians towards tourists and foreigners was noted, even by the interviewees who complain about touristification. Although such discriminatory denunciation is not completely refuted in these times of intolerance.

If a "repudiation of touristification" is considered, as defined by the Fundación del Español Urgente, in fact, there would be tourismophobia in Poblenou due to the protests and complaints against tourism gentrification. However, many respondents recognised the importance of tourism and complained about the negative impacts as something that needs to be regulated. Furthermore, when citing tourismophobia, the media does not mention or discuss touristification and its impacts.

Therefore, this evidence of tourism gentrification meets the complaints of neighbourhood associations and activists that tourismophobia is "not neutral (term)" (DOMÍNGUEZ, 2018, p. 23); of this "nickname" as political instrumentalisation and media sensationalism (MILANO, 2018); and the idea of an "ideological struggle between two well-defined and clearly antagonistic positions that fight to impose their definition of the situation" (HUETE; MANTECÓN, 2018, p. 17). Therefore, when using the suffix phobia, the term resembles politically correct struggles against homophobia, xenophobia, etc., giving a discriminatory meaning that, in turn, minimises claims against touristification.

\section{Conclusion}

Considering so many investments in marketing and infrastructure, Poblenou has become an increasingly coveted place for companies, the middle class and tourist services. Since the Olympic Games, it has been a gentrification process, which associated with touristification results in tourism gentrification. The impacts of these changes range from replacing traditional trade with more elite services to the exodus of former residents and workers who are no longer able to live in the neighbourhood due to increased costs. The Municipality recognised the population's claims and outlined some actions to mitigate the impacts of tourism, such as the reorganisation of La Rambla Poblenou terraces and limiting accommodation.

At the same time, a debate about tourismophobia emerged, whose complexity has been presented since it was defined. If it were considered as a "rejection of touristification", there would be tourismophobia in Poblenou. However, those who accuse tourismophobia do not mention and/or explain touristification and its impacts. On the contrary, this fear is presented in a similar way to politically correct claims against homophobia and xenophobia, adding sensationalism, a discriminatory character and some confusion in this discussion. Understood as a discriminatory reaction to tourists, there was no evidence of such practices, although this possibility is not ruled out.

128 Simas, T. B.; Oliveira, S. A. Le C. de; Cano-Hila, A. B. 
As scientific research aims to find a reality that is often covered by the reality represented, the result of intense publicity and the media (MARICATO, 2013), this investigation understands that this classification of tourismophobia, that was so covered and disseminated by the Spanish media in 2017, is a neoliberal reaction or strategy of those interested in tourism that are distorting the facts and creating a "smoke screen" because of their economic losses. Although this research has not exhausted this topic, the study of this experience allows us to advance in this knowledge gap in urban and tourism studies and to reveal the need for further investigations considering its definition, possible "cases" of discrimination and tourism gentrification. Considering that the Barcelona Model has become a reference for many cities in the world, it is important to promote further this debate on touristification and tourismophobia, which can go beyond the case of Poblenou, so that other communities in the world and their researchers can be cautious about such processes and possible reactionary discourses.

\section{References}

AJUnTAMENT DE BARCELONA. Àmbit Pilot de Superilles. Districte de Sant Martí. Barri del Poblenou - Informe Diagnòstic. Barcelona, 2015.

AJUNTAMENT DE BARCELONA. ¿Qué es el PEUAT?. Available at: http://ajuntament.barcelona.cat/pla-allotjaments-turistics/es/. Access: 4 jan. 2018.

ARANTES, O. Uma estratégia fatal: A cultura nas novas gestões urbanas. In: ARANTES, O.; VAINER, C.; MARICATO, E. (org.). A cidade do pensamento único: desmanchando consensos. Petrópolis: Vozes, 2013.

BARCELONA. 2016: informe de la actividad turística en Barcelona. Barcelona: Gabinet d'Estudis Econòmics de la Cambra de Comerç de Barcelona, 2017.

BENI, M. C.; MOESCH, M. A teoria da complexidade e o ecossistema do turismo. Turismo - Visão e Ação, v. 19, n. 3, p. 430-457, 2017.

BOOKING. Booking. Available at: https://www.booking.com/. Access: 04 de jan. 2018.

BORJA, J.; MUXÍ, Z. Urbanismo en el siglo XXI: una visión crítica. Bilbao, Madrid, Valencia, Barcelona. In: MONTANER, J. M. et al. Reader modelo Barcelona, 1973-2013. Barcelona: Comanegra, 2013.

CALVENTE, M. C. M. H. Turismo e território-rede: o problema da multiterritorialidade restrita das populações tradicionais. Caderno Virtual de Turismo, Rio de Janeiro, v. 13, n. 1, p.120-133, abr. 2013.

CARTA CAPITAL. Barcelona contra o turismo. Available at:

http://www.cartacapital.com.br/internacional/barcelona-contra-o-turismo. Access: 3 feb. 2017.

COMPANS, R. Empreendedorismo urbano: entre o discurso e a prática. São Paulo: Editora UNESP, 2005.

DELGADO, M. La ciudad mentirosa: fraude y miseria del 'Modelo Barcelona'. [S.1.]: Catarata, 2010.

DEPARTAMENT D’ESTADÍSTICA DEL AJUNTAMENT DE BARCELONA. Oficina municipal de Dades. Available at: http://www.bcn.cat/estadistica/catala/index.htm. Access: 11 jan. 2018.

DIAS, R. Sociologia do turismo. São Paulo: Atlas, 2008.

DOMíngueZ, A. Q. Turismofobia, ou o turismo como fetiche. Revista do Centro de Pesquisa e Formação SESC, São Paulo, p. 22-30, jun. 2018.

EL ANTROPÓLOGO PERPLEJO. Poblenou. Available at: https://antroperplejo.wordpress.com/tag/poblenou/. Access: 22 may 2017.

EL DIARIO. Barcelona ordena cerrar 256 pisos turísticos ilegales en un mes. Available at: http://www.eldiario.es/catalunya/barcelona/Barcelona-cerrar-viviendas-turistico-ilegal_0_546645808.html. Access: 10 Jan. 2018.

EL PERIÓDICO. La instalación de un albergue juvenil de 440 plazas moviliza a la Vila Olímpica. Available at: https://www.elperiodico.com/es/sant-marti/20161018/la-construccion-de-un-albergue-juvenilde-440-plazas-moviliza-a-la-vila-olimpica-5565660. Access: 18 Feb. 2018.

EL POBLENOU. Continuen desapareixent passatges al Poblenou Aprovació de la modificació d'un pla urbanístic: Pla Ramon Turró, Tortellà, Pellaires. Revista El Poblenou, v. 90, p. 7, p.7, fev. 2016. 
FLORES, L. N. T.; VARGAS, A. R. B. Turismofobia: un breve análisis de casos relevantes. In: CONGRESO VIRTUAL INTERNACIONAL DESARROLLO ECONÓMICO, SOCIAL Y EMPRESARIAL EN IBEROAMÉRICA, 4., Málaga, 2019. Anais [...] Málaga, 2019.

GIULIANOTTI, R. et al. Global sport mega-events and the politics of mobility. The British Journal of Sociology, v. 66, n. 1, p. 118-140, 2015.

GOOGLE EARTH. 2017. [Image]. Available: https://www.google.com.br/earth/download/gep/agree.html. Access: 15 jan. 2017.

HARVEY, D. Cidades rebeldes: do direito à cidade à revolução urbana. São Paulo: Martins Fontes, 2014.

HARVEY, D. Para entender O capital. São Paulo: Boitempo, 2013.

HILLER, H. H. Post-event outcomes and the post-modern turn: the olympics and urban transformations. European Sport Management Quarterly, v. 6, n. 4, p. 317-332, 2006.

HUETE, R.; MANTECÓN, A. El auge de la turismofobia ¿hipótesis de investigación o ruido ideológico? PASOS. Revista de Turismo y Patrimonio Cultural, v. 16, n. 1, p. 9-19, 2018.

INICIATIVA DEBATE. Turismofobia, tu padre. Available at: http://iniciativadebate.net/2017/08/07/turismofobia-tu-padre/. Access: 18 feb. 2018.

JACQUES, P. B. Errâncias urbanas: a arte de andar pela cidade. Caminhos alternativos à espetacularização das cidades. ARQTEXTO, Porto Alegre, v. 7, p. 16-25, 2005.

KOOLHAAS, R. Três textos sobre a cidade: grandeza, ou o problema do grande; a cidade genérica; espaço-lixo. Barcelona: Gustavo Gili, 2014.

LEFEBVRE, H. O direito à cidade. Itapevi: Nebli, 2016.

LIMA JUNIOR, P. N. Uma estratégia chamada "planejamento estratégico": deslocamentos espaciais e a atribuição de sentidos na terapia do planejamento urbano. Rio de Janeiro: 7 Letras, 2010.

MARICATO, E. As ideias fora do lugar e o lugar fora das ideias: Planejamento urbano no Brasil In: ARANTES, O.; VAINER, C.; MARICATO, E. (org.). A cidade do pensamento único: desmanchando consensos. Petrópolis: Vozes, 2013.

MENDES, L. Gentrificação turística em Lisboa: neoliberalismo, financeirização e urbanismo austeritário em tempos de pós-crise capitalista 2008-2009. Cadernos Metrópole, São Paulo, v. 19, n. 39, p. 479-512, may/aug. 2017.

MILANO, C. Overtourism, malestar social y turismofobia: un debate controvertido. PASOS. Revista de Turismo y Patrimonio Cultural, v. 16, n. 3, p. 551-564, 2018.

MILANO, C. Turismofobia: cuando el turismo entra en la agenda de los movimientos sociales. Revista de la Taula Veïnal d'Urbanisme de BARCELONA, v. 1 n. 1, apr. 2017.

MONTANER, J. M.; MUXÍ, Z. Arquitetura e política: ensaios para mundos alternativos. São Paulo: Gustavo Gili, 2014.

NACIODIGITAL. EI govern de Colau vol ressuscitar el 22@. 2017. Available at: http://www.naciodigital.cat/noticia/124165/govern/colau/vol/ressuscitar/22. Access: 17 May 2017.

OBSERVATORIO METROPOLITANO DE MADRID. EI Mercado contra la ciudad: sobre globalización, gentrificación y políticas urbanas. Madrid: Traficantes de Sueños, 2015.

OLIVEIRA, M. F. S.; OLIVEIRA, O. J. R. Estado e turismo: trajetórias do caso baiano. Caderno Virtual de Turismo, Rio de Janeiro, v. 12, n. 3, p. 384-398, dez. 2012.

OLIVEIRA, T. A. B. Porto: turistificação e turismofobia. Porto, 2019. Dissertation (Master's) - Faculdade de Letras, Universidade do Porto, Porto, 2019.

PÉREZ, X. P. Turismo Cultural: uma visão antropológica. Tenerife: ACA y PASOS, RTPC, 2009.

PORRETTA, D. De la Barcelona ciudad a la marca Barcelona. In: MONTANER, J. M. et al. Reader Modelo Barcelona, 1973-2013. Barcelona: Comanegra, 2013.

ROCHE, M. Mega-events, time and modernity: on time structures in global society. Time \& Society, v. 12, n. 1, p. 99-126, 2003.

130 Simas, T. B.; Oliveira, S. A. Le C. de; Cano-Hila, A. B. 
SIMAS, T. B. A competição das cidades pela inovação e os processos de gentrificação nos casos Porto Digital em Recife e 22@Barcelona. Rio de Janeiro, 2018. Thesis (Doctorate) - Programa de PósGraduação em Urbanismo, Universidade Federal do Rio de Janeiro, Rio de Janeiro, 2018.

SMITH, N. Nuevo Globalismo y nuevo urbanismo. La gentrificación como estrategia urbana local. In: OBSERVATORIO METROPOLITANO DE MADRID (org.). El Mercado contra la ciudad: sobre globalización, gentrificación y políticas urbanas. Madrid: Traficantes de sueños, 2015.

VAINER, C. Pátria, empresa e mercadoria. In: ARANTES, O.; VAINER, C.; MARICATO, E. (org.). A cidade do pensamento único: desmanchando consensos. Petrópolis: Vozes, 2013.

VASCONCELOS-DE-LIMA, E. L. Nas tramas e falácias do planejamento urbano estratégico: marketing urbano, Modelo Barcelona e megaeventos. Boletim Goiano de Geografia, v. 35, p. 217-235, 2015.

VÁZQUEZ, E. R.; DAVILA, J. de la C. Turismofobia: un análisis social desde los medios de comunicación. Boletín Científico INVESTIGIUM, v. 5, n. 10, p. 33-37, 2020.

\section{Tarciso Binoti Simas}

Instituto de Engenharia do Araguaia | Universidade Federal do Sul e Sudeste do Pará | Rua Geraldo Ramalho, s/n, Centro | Santana do Araguaia - PA - Brasil |CEP 68560-000 | Tel.: (94) 2101-5936 | E-mail: tarcisobinoti@gmail.com

Sônia Azevedo Le Cocq de Oliveira

Programa de Pós-Graduação em Urbanismo | Universidade Federal do Rio de Janeiro | Av. Reitor Pedro Calmon, 550, Prédio da FAU/Reitoria, $5^{\circ}$ andar, sala 521, Cidade Universitária | Rio de Janeiro - RJ - Brasil | CEP 21941-901 | Tel.: (21) 3938-0287 |

E-mail: sonialecocq@gmail.com

\section{Ana Belén Cano-Hila}

Departament de Sociologia | Universitat de Barcelona | Diagonal, 690 | Barcelona - Catalunha - Espanha | 08034| Tel.: +(34) 9340-39854 | E-mail: anabelencano@ub.edu

\section{Ambiente Construído}

Revista da Associação Nacional de Tecnologia do Ambiente Construído Av. Osvaldo Aranha, $99-3^{\circ}$ andar, Centro

Porto Alegre - RS - Brasil

$$
\text { CEP } 90035-190
$$

Telefone: +55 (51) 3308-4084

www.seer.ufrgs.br/ambienteconstruido

www.scielo.br/ac

E-mail: ambienteconstruido@ufrgs.br

This is an open-access article distributed under the terms of the Creative Commons Attribution License. 